\title{
Kerentanan Perempuan dalam Surveillance Capitalism
}

\author{
Bergita P. Pricelia Lejo \\ Nestlé Indonesia \\ ^Penulis Koresponden: Pricelia90@gmail.com
}

\section{ABSTRAK}

Tulisan ini bertujuan untuk menganalisa kerentanan perempuan terhadap Kekerasan Gender Berbasis Online (KGBO) di dalam ruang digital. Studi ini menggunakan konsep kapitalisme pengawasan/surveillance capitalism dan symbolic violence sebagai dasar untuk memahami logika ekonomi dan juga kekerasan yang berlangsung dalam ruang digital. Ruang digital sebagai alat ekonomi tidak hanya menghasilkan "behavioral surplus" sebagai material baru tetapi juga menjadi ruang bagi terbentuknya "dominant habitus" tentang siapa itu perempuan dan bagaimana seharusnya perempuan merepresentasikan dirinya. Dominant habitus yang senantiasa direproduksi mampu menciptakan kebutuhan ekonomi bagi perempuan melalui komodifikasi dan bahkan eksploitasi terhadap tubuh perempuan yang terepresentasi dalam teks gambar, dan video di dalam platform digital. Melalui proses-proses ini, perempuan mengalami kekerasan simbolik yang terus-menerus direproduksi dalam dominant habitus. Dengan demikian, bekerjanya surveillance capitalism dan menguatnya dominant habitus di dalamnya menjadi kondisi yang membuka ruang bagi berlangsungya KGBO terhadap perempuan. Dengan menggunakan perspektif kritis dalam memandang KGBO tulisan ini hendak mendalami proses-proses yang mengkondisikan kerentanan perempuan di dalam ranah digital. Pemahaman akan hal-hal tersebut menjadi basis penting untuk memikirkan secara tepat posisi perempuan di dalam ruang digital yang saat ini secara luas diterima sebagai condition sine qua non yang di dalamnya berbagai bentuk relasi berlangsung. Dengan demikian, tulisan ini memberikan pijakan dasar untuk mendorong dan merumuskan beberapa agenda perubahan.

Kata Kunci: KGBO; Kapitalisme Pengawasan; Kekerasan Simbolik

\section{ABSTRACT}

This paper aims to analyze women's vulnerability to Online-Based Gender Violence (KGBO) in the digital platform. This study uses the concept of surveillance capitalism and symbolic violence as a basis for understanding the economic logic and violence that takes place in today's digital platform. Digital platform as an economic tool not only produces a "behavioral surplus" as a new material, but also becomes a space for the formation of a "dominant habitus"; who is women are and how women should represent themselves. Dominant habitus which is always reproduced is able to create economic needs for women through commodification and even exploitation of women's bodies which are represented in text, images and videos on digital platforms. Throughout these processes, mostly women suffer from symbolic violence which persistently reproduced by the dominant habitus. It obviously reflects the vulnerability of woman as the victim of $K G B O$. By using a critical perspective in looking at $K G B O$, this paper intends to explore the process that put women's vulnerability in the digital arena. Understanding of these matters becomes an important basis for thinking about the exact position of women in the digital space which is currently widely accepted as a condition sine qua non in which various forms of relations take place. Thus, this paper provides a basic basis for encouraging and formulating several agendas for change.

Kata Kunci: Online-Based Gender Violence; Surveillance Capitalism; Symbolic Violence

\section{PENDAHULUAN}

Bergesernya aktifitas sosial menjadi virtual dan terbatasnya mobilitas manusia selama pandemi berdampak pada peningkatan yang signifikan terhadap penggunaan internet di Indonesia. Pertumbuhan penggunaan internet di Indonesia pada Januari 2021 telah mencapai 15.5\% apabila 
dibandingkan dengan Januari 2020, dengan cakupan populasi mencapai $73.7 \%{ }^{1}$. Peningkatan penggunaan internet selama pandemi ternyata juga telah menambah jumlah yang signifikan pada kemunculaan Kekerasan Gender Berbasis Online (KGBO) di Indonesia. Sampai dengan Oktober tahun 2020 setidaknya ada 659 kasus KGBO yang dilaporkan meningkat lebih dari 130\% bila dibandingkan dengan kasus terlapor di tahun 2019 yang mencapai 281 kasus $^{2}$.

Berangkat dari kondisi tersebut penulis mencoba untuk melihat KGBO dengan menggunakan konsep kapitalisme pengawasan/ surveillance capitalism. Surveillance capitalism sebagai sebuah proses ekonomi produksi yang melekat pada ruang digital sebagai alat, telah menjadikannya ruang bagi terbentuknya material baru atau yang oleh Zuboff disebut sebagai "behavioral surplus". Tidak hanya itu, ruang digital juga bergerak sejalan dengan dikembangkannya "dominant habitus" yang terstruktur mengenai bagaimana seharusnya menjadi perempuan. Tubuh perempuan menjadi objek ekonomi yang sarat dengan komodifikasi dan eksploitasi yang justru digerakkan oleh perempuan sendiri di dalam ruang digital. Perempuan mengalami kekerasan simbolik di ruang digital yang memberikan peluang bagi berkembangnya kekerasan gender berbasis online.

Kebaruan dari tulisan ini adalah memberikan perspektif kritis terhadap terbentuknya KGBO di ruang digital dengan menggambungkan dua konsep yaitu surveillance capitalism dan dominant habitus. Dengan demikian diharapkan perempuan lebih memiliki kesadaran atas partisipasinya didalam ruang digital yang sarat dengan logika ekonomi dan orientasi keuntungan. Selanjutnya bagaimana pemerintah mengatur perlindungan terhadap data pribadi pengguna dan peningkatan literasi digital di kalangan masyarakat sebagai prioritas utama di tengah merebaknya kasus Kekerasan Gender Berbasis Online (KGBO).

\section{TINJAUAN PUSTAKA}

Peta studi mengenai Kekerasan Gender Berbasis Online (KGBO) sejauh ini banyak di dukung oleh analisa yang menekankan pada dua hal yaitu, pertama, perspektif hukum dalam melihat potensi penyebaran data pribadi di ruang online dan penyelesaian kasus KGBO. Kedua, perspektif gender untuk melihat pola-pola kekerasan yang terbentuk di ruang online melalui konsep gender inferiority yang banyak menjadi titik masuk bagi pelaku dalam melancarkan aksi kekerasannya. Studi dengan tema besar KGBO banyak menekankan pada pembahasan bentuk- bentuk KGBO seperti non-consentual pornography atau revenge pornography ${ }^{3}$; penyebaran data/video pribadi yang mayoritas menempatkan perempuan sebagai korban dan menilik peran penegakan hukum terhadap kasus. Studi KGBO juga melihat sejauh mana peran penegak hukum dalam merespon

\footnotetext{
${ }^{1}$ Galuh Putri Riyanto, “Jumlah Pengguna Internet Indonesia 2021 Tembus 202 Juta”, Kompas.com, 23 Februari 2021, https:/tekno.kompas.com/read/2021/02/23/16100057/jumlah-pengguna-internet-indonesia-2021-tembus-202-juta

${ }^{2}$ F. Wisnu Wardhana Dany, "Pemerasan Seksual Manfaatkan Data Korban di Daring", 4 Maret, 2021 https://www.kompas.id/baca/polhuk/2021/03/04/pemerasan-seksual-manfaatkan-data-korban-di- daring/

${ }^{3}$ Sophie Maddocks (2018): From Non-consensual Pornography to Image-based Sexual Abuse: Charting the Course of a Problem with Many Names, Australian Feminist Studies, 2-3, https://doi.org/10.1080/08164649.2018.1542592
} 
kasus dengan berbagai tantangannya seperti inkonsistensi hukum, minimnya sumberdaya dan bukti serta isu-isu seperti victim blaming dalam proses mengatasi $\mathrm{KGBO}^{4}$.

Berangkat dari pemaparan tersebut penting untuk memberikan pemahaman terkait ruang digital yang tidak bebas nilai dan bagaimana logika ekonomi bergerak dalam Surveillance Capitalism. Kondisi ini menempatkan kekerasan gender bukan hanya sebagai fenomena kekerasan yang telah hadir sebelum berkembangnya ruang digital, tetapi bagaimana ruang digital kemudian juga memberikan ruang bagi lahirnya KGBO. Studi ini diharapkan mampu memberikan perspektif baru dalam melihat kekerasan melalui perspektif yang lebih kritis dalam memahami arena dimana kekerasan ini berlangsung.

\section{KERANGKA PIKIR DAN METODOLOGI}

Dengan menggunakan studi pustaka dan data sekunder, tulisan ini berupaya memberikan perspektif kritis terhadap isu Kekerasan Gender Berbasis Online (KGBO) yang berkembang secara signifikan di Indonesia. Studi ini menggabungkan dua konsep utama yaitu Surveillance Capitalism sebagai sebuah sistem ekonomi baru yang menggerakan ruang-ruang digital saat ini serta konsep dominant habitus Bordieu. Surveillance Capitalism dengan logika ekonominya memiliki orientasi profit dengan memanfaatkan behavioral surplus yang diperolehnya dari ruang digital. Sedangkan dominant habitus adalah habitus yang dibentuk oleh sistem yang terstruktur di dalam ruang digital dan direproduksi oleh pengguna internet. Dominant habitus yang bergerak di dalam sistem digital ini memunculkan kekerasan simbolik terhadap perempuan melalui pola-pola komodifikasi dan eksploitasi terhadap tubuh perempuan. Dalam proses inilah kekerasan simbolik bisa menjadi ruang bagi terbentuknya Kekerasan Gender Berbasis Online (KGBO).

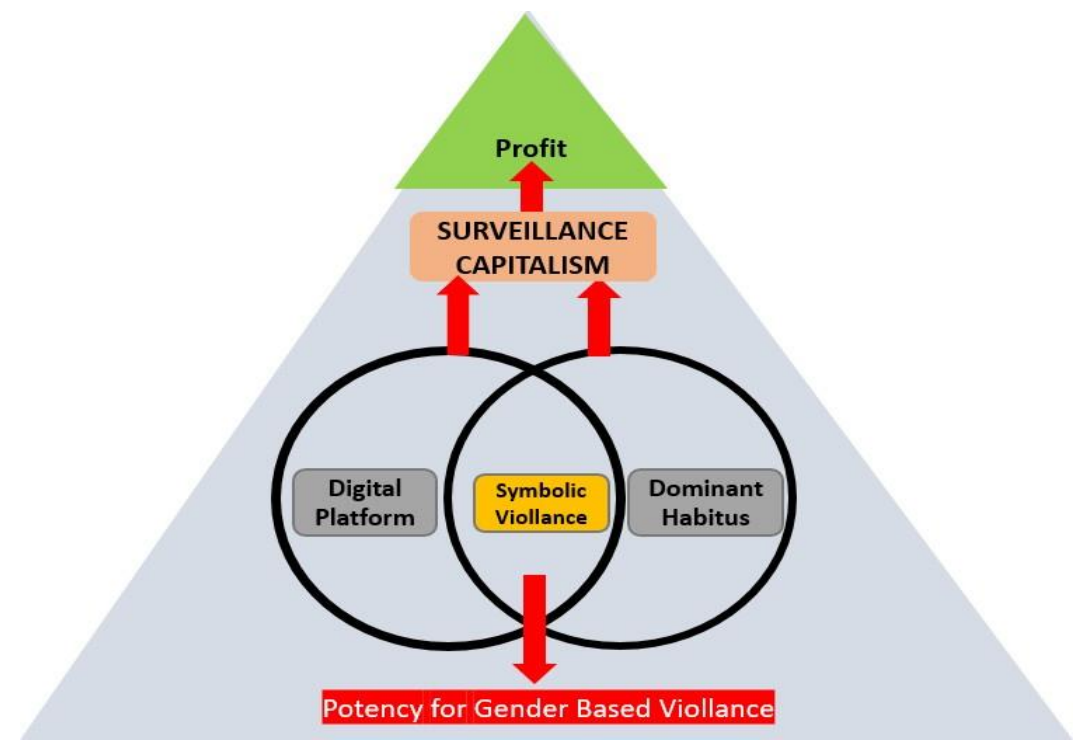

Gambar 1. Kerangka Berpikir

\footnotetext{
${ }^{4}$ Nicola Henry, Asher Flynn \& Anastasia Powell (2018) Policing image-based sexual abuse: stakeholder perspectives, Police Practice and Research, 19:6, 565-581, https://doi.org/10.1080/15614263.2018.1507892
} 


\section{HASIL DAN PEMBAHASAN}

\section{Perkembangan Kekerasan Gender Berbasis Online Di Era Pandemi}

Penggunaan teknologi digital selama pandemi mengalami peningkatan yang signifikan di Indonesia. Menurut data yang dihimpun oleh Kompas, pada Januari 2021 mengalami pertumbuhan sebesar $15.5 \%$ dibandingkan dengan Januari $2020^{5}$. Jumlah pengguna Internet yang mencapai $73.7 \%$ total populasi di Indonesia menjelaskan tingginya partisipasi masyarakat dalam berselancar di dunia maya saat ini. Periode pandemi yang dimulai pada awal tahun 2020 menjadi salah satu momentum yang sangat penting dalam proses perkembangan internet secara khusus di Indonesia. Penggunaan internet telah mengambil peran penting dalam proses kehidupan masyarakat selama era pandemi. Tidak hanya bersifat sebagai hiburan, penggunaan internet mengambil bagian dalam setiap lini kehidupan masyarakat saat ini, baik itu pekerjaan, aktifitas belajar mengajar, pertemuan sosial, hingga proses jual beli barang dan jasa yang memanfaatkan applikasi e-commerce dan fintech.

Di sisi lain hal yang menjadi perhatian adalah peningkatan penggunaan internet selama pandemi ternyata diikuti juga dengan banyaknya kasus kejahatan siber yang dilaporkan oleh masyarakat. Berikut adalah data yang dikutip dari media nasional Kompas berdasarkan laporan yang di peroleh oleh kepolisian terkait trend jumlah kejahatan siber dan jenisnya;

\begin{tabular}{|c|c|c|c|c|c|c|}
\hline \multicolumn{7}{|c|}{ Tren Jumlah Kejahatan Siber } \\
\hline & $2020^{*}$ & 2019 & 2018 & 2017 & 2016 & 2015 \\
\hline Laporan ke kepolisian & 4.250 & 4.586 & 4.360 & 3.109 & 3.110 & 2.609 \\
\hline Kasus selesai & $\begin{array}{l}\text { Belum } \\
\text { ada data }\end{array}$ & 2.284 & 2.273 & 1.610 & 908 & 624 \\
\hline \multicolumn{7}{|c|}{ 'Berdasarkan laporan ke kepolisian hingga November 2020} \\
\hline \multicolumn{7}{|c|}{ Jenis Kejahatan Siber } \\
\hline & $2020^{*}$ & 2019 & 2018 & 2017 & 2016 & 2015 \\
\hline Penipuan daring & 1649 & 1.617 & 1.781 & 1.430 & 1.570 & 1.494 \\
\hline $\begin{array}{l}\text { Penyebaran } \\
\text { konten provokatif }\end{array}$ & 1.04 & $8 \longdiv { 1 . 7 6 9 }$ & 1.724 & 1.157 & 1.047 & $7 \square 715$ \\
\hline Pornografi & I208 & 364 & I266 & | 180 & I 155 & I 135 \\
\hline Akses ilegal & | 138 & 248 & 【263 & | 153 & I 147 & | 107 \\
\hline Perjudian & 32 & 135 & 135 & 124 & 26 & 16 \\
\hline Pemerasan & 19 & I132 & 136 & 22 & 17 & 18 \\
\hline $\begin{array}{r}\text { Pencurian data/ } \\
\text { identitas }\end{array}$ & | 39 & 1143 & 188 & 147 & 120 & 149 \\
\hline $\begin{array}{r}\text { Peretasan } \\
\text { sistem elektronik }\end{array}$ & 18 & I148 & 143 & 135 & 0 & 0 \\
\hline Intersepsi ilegal & 24 & 3 & 5 & 10 & 15 & 7 \\
\hline $\begin{array}{r}\text { Pengubahan } \\
\text { tampilan situs }\end{array}$ & 9 & 4 & 5 & 5 & 142 & 127 \\
\hline Gangguan sistem & 4 & 9 & 1 & 13 & 171 & 141 \\
\hline Manipulasi data & 171 & 1114 & 1113 & 133 & 0 & 0 \\
\hline
\end{tabular}

(Sumber: Kompas, 30 Maret 2021, Pelaku Ekonomi Digital Butuh Otoritas Perlindungan Data) ${ }^{6}$

\footnotetext{
5 Galuh Putri Riyanto, “Jumlah Pengguna Internet Indonesia 2021 Tembus 202 Juta”, Kompas.com, 23 Februari 2021 , https:/tekno.kompas.com/read/2021/02/23/16100057/jumlah-pengguna-internet-indonesia-2021- tembus-202-juta

${ }^{6}$ M Paschalia Judith J, "Pelaku Ekonomi Digital Butuh Otoritas Perlindungan Data", 30 Maret, 2021, https://www.kompas.id/baca/ekonomi/2021/03/30/pelaku-ekonomi-digital-butuh-otoritas-perlindungan-data/
} 
Berdasarkan data yang ditampilkan diatas kita dapat melihat bahwa sampai dengan laporan yang diterima pada bulan Juni 2020, total kasus telah mencapai 4250 kasus. Angka ini sangat signifikan bertambah bila dibandingkan dengan total laporan pada tahun 2019 yang mencapai 4586. Kontributor tertinggi kasus kejahatan siber di Indonesia tertinggi adalah pada penyebaran informasi provokatif, penipuan daring, pornografi, dan akses illegal yang menyumbang rata-rata 90\% dari total kejahatan siber yang di laporkan dalam lima tahun terakhir.

Sedangkan laporan Kekerasan Gender Berbasis Online (KGBO) pun mengalami peningkatan yang cukup signifikan terlepas dari terbatasnya akses dan mobilitas orang untuk melaporkan kasus selama pandemi berlangsung. Berdasarkan data yang dihimpun oleh Komnas Perempuan terjadi peningkatan yang signifikan mencapai 659 kasus atau meningkat 135\% bila dibandingkan dengan laporan pada tahun 2019. Kasus dengan kontribusi tertinggi adalah ancaman Distribusi foto/video pribadi (malicious distribution), konten illegal, dan tindakan pendekatan untuk memperdaya (cyber grooming).

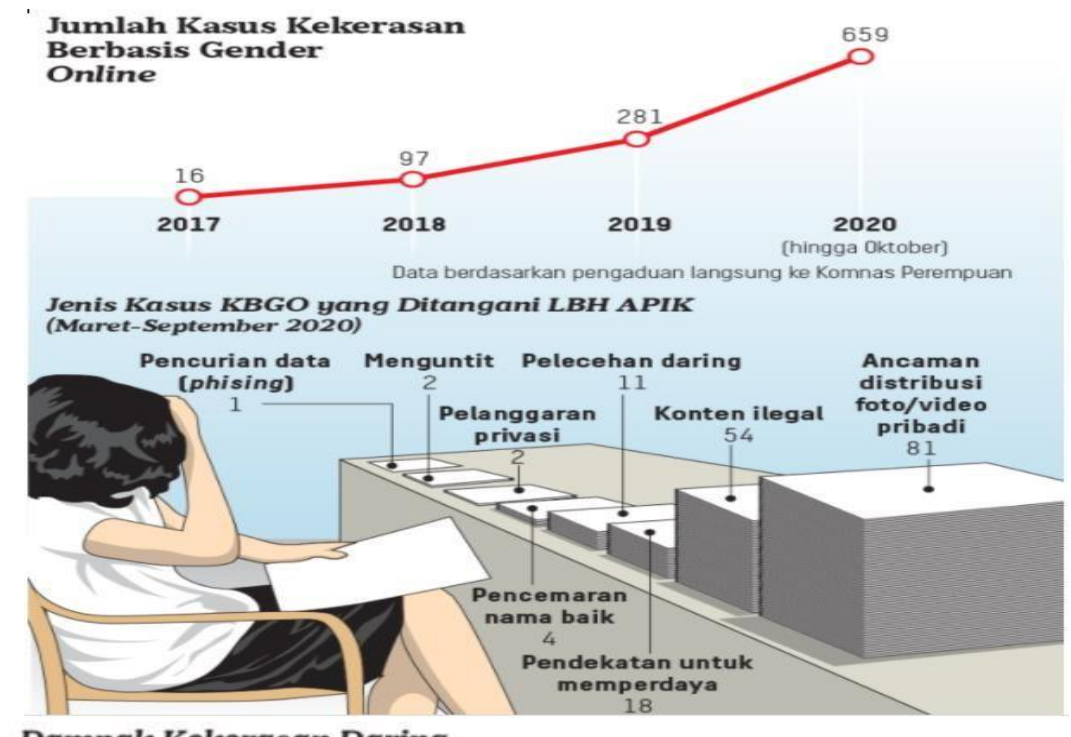

Dampak Kekerasan Daring

Lembaga Plan International melakukan survei kepada 14.071 perempuan berusia 15-25 tahun di 22 negara. Survei dilaksanakan pada 1 April-5 Mei 2020.

Stres mental atau emosional

$\begin{array}{ll}\text { Kehilangan kepercayaan diri } & 42 \% \\ \text { Merasa tidak aman secara fisik } & 42 \%\end{array}$

Merasa tidak aman secara fisik $24 \%$

Bermasalah dengan teman atau keluarga

Bermasalah di sekolah $19 \%$

Bermasalah dalam mencari atau

Bermasalah dalam mencari atau bertahan di tempat kerja

Lainnya

$2 \%$

Responden dapat memilih lebih dari satu jawaban

Sumber. Komnas Perempuan. LBH APIK, dan Plan Internationat Diolah Litbang Kompas/WRD/DEB

(Sumber: Kompas, 4 Maret 2021, Pemerasan Seksual Manfaatkan Data Korban di Daring) ${ }^{7}$

\footnotetext{
${ }^{7}$ F. Wisnu Wardhana Dany, "Pemerasan Seksual Manfaatkan Data Korban di Daring”, 4 Maret, 2021

https:/www.kompas.id/baca/polhuk/2021/03/04/pemerasan-seksual-manfaatkan-data-korban-di- daring/
} 
KGBO dapat muncul dalam berbagai berbagai bentuk seperti memperdaya (cyber grooming), pelecehan daring (cyber harassment), peretasan (hacking), konten ilegal (illegal content), pelanggaran privasi (infringement of privacy), ancaman distribusi foto/video pribadi (malicious distribution), pencemaran nama baik (online defamation), pengelabuan (phising), dan perekrutan daring (online recruitment). Banyaknya variasi bentuk Kekerasan Gender Berbasis online menjelaskan tingginya resiko bagi pengguna internet di ruang digital dan bagaimana kekerasan dapat terjadi dalam berbagai bentuk.

Hal ini juga menjadi dasar pentingnya menilik kembali secara kritis ruang digital sebagai tempat terjadinya tindak kekerasan gender berbasis online. Dengan demikian diharapkan perempuan memiliki kesadaran akan potensi resiko atas perilaku di dalam ruang digital agar tidak berkontribusi pada terbentuknya kekerasan simbolik. Sekaligus bagaimana dalam lingkup yang lebih makro pemerintah perlu meningkatkan sosialisasi terkait literasi digital dan membuat regulasi yang tepat terkait perlindungan data pribadi masyarakat.

\section{Kerentanan Perempuan dalam Kapitalisme Pengawasan (Surveillance Capitalism)}

Meningkatnya Kekerasan Gender Berbasis Online (KGBO) khususnya di era pandemi perlu ditelaah dengan perspektif kritis yang menempatkan Kapitalisme Pengawasan/ Surveillance Capitalism sebagai sistem yang memungkinkan munculnya tindakan KGBO. Surveillance Capitalism sebagai sistem ekonomibaru yang berorientasi pada profit menempatkan ruang digital sebagai alat ekonomi penting yang tidak bisa dipisahkan dari sistem itu sendiri. Mengutip apa yang disampaikan oleh Zuboff, "If technology is bone and muscle, surveillance capitalism is the soft tissue that binds the elements and directs them into action. Surveillance capitalism is an economic creation, and it is therefore subject to democratic contest, debate, revision, constraint, oversight, and may even be outlawed." Ranah digital yang di maksudkan disini adalah seluruh ekosistem digital yang terlibat dalam teknologi internet yang kita gunakan hari ini; mulai dari ponsel pintar hingga berbagai aplikasi yang kita gunakan dalam bermedia sosial, sistem mesin pencari, hingga aplikasi e-commerce dan berbagai bentuk aplikasi yang disajikan. Ruang digital yang kita manfaatkan hari ini bukanlah semata alat yang mempermudah komunikasi dan berbagai aktifitas kehidupan tetapi juga sarat dengan berbagai kepentingan ekonomi, sosial-politik maupun budaya. Sehingga penting untuk pengguna teknologi internet memahami konteks dari perkembangan dunia digital hari ini dengan perspektif kritis.

Dalam surveillance capitalism kita mengenal konsep "behavioral surplus" yaitu data perilaku pengguna internet tidak hanya menyangkut identitas melainkan juga preferensi terhadap kebutuhan jasa dan produk, hingga mobilitas dan kebutuhan personal individu. Prediksi terhadap perilaku manusia ini yang kemudian menjadi material baru dalam sistem ekonomi ini untuk kemudian diredistribusikan kepada pihak-pihak/perusahaan sehingga mereka memiliki prediksi

\footnotetext{
${ }^{8}$ Shoshana Zuboff, "Surveillance Capitalism and the Challenge of Collective Action", The Murphy Institute, City University of New York, (2019):1.
} 
produksi yang lebih akurat terhadap target pasar mereka. Seperti yang dijelaskan oleh Zuboff, "Behavioral data that were once discarded or ignored were rediscovered as what I call behavioral surplus; ...this new market exchange was not an exchange with users but rather with companies who understood how to make money from bets on users' future behavior." "Menurut hemat penulis, hal ini kemudian menjelaskan tentang personalisasi iklan yang kita dapatkan dalam bermedia sosial, bahkan bagaimana sistem digital menyediakan saran/ "suggestion" untuk hal-hal yang harus kita tonton atau ikuti. Dalam hal ini ruang digital telah bergerak dalam logika ekonomi tidak hanya memahami perilaku manusia sebagai potensi pasar melainkan juga menciptakan kebutuhan ekonomi dikalangan penggunanya.

Lalu bagaimanakah kita memahami perempuan sebagai individu yang rentan dalam sistem ini? Berangkat dari ruang digital yang sarat dengan berbagai kepentingan kita perlu melihat bagaimanakah dominant habitus perempuan berkembang dalam platform ini. Instagram sebagai salah satu platform digital terbesar saat ini dengan lebih dari 1 Milyar pengguna dapat menjelaskan bagaimana habitus perempuan direpresentasikan dalam teks, gambar, dan video.

Kecenderungan yang berkembang hari ini adalah bagaimana Instagram sebagai ruang media sosial menggambarkan kecantikan perempuan dengan berbagai standard seperti bentuk tubuh dan wajah, bagaimana perempuan harus mengikuti trend mode tertentu, dan berbagai gaya hidup seperti jenis olahraga, dan aktifitas waktu luang yang dianggap menjadi ukuran wanita cantik dan berkelas. Figur perempuan yang sempurna ditampilkan oleh publik figur dan menjadi dominant habitus yang diikuti oleh banyak perempuan untuk dapat memperoleh image/gambaran yang serupa dengan apa yang diimajinasikan sebagai kesempurnaan itu sendiri.

Dalam proses berlangsungnya dominant habitus yang direproduksi oleh sistem digital maupun kalangan perempuan sendiri sesungguhnya telah memberikan ruang bagi terbentuknya apa yang kemudian dijelaskan oleh Bordieu sebagai "symbolic viollance", "However, since the victims "do not recognize" the violence, those practices seem to be normal and are rarely criticized. Generally speaking, symbolic violence is the violence whose victims "approve" the act of violence. Bourdieu argues the symbolic violence occurs in almost every aspect of society. "10 Sebagian besar pengguna internet dalam ini perempuan secara sadar atau tidak telah mengalami kekerasan simbolik ketika kita menjadikan tubuh perempuan sebagai suatu objek yang menjadi sangat mudah dikomodifikasi dan bahkan dieksploitasi demi kebutuhan bahan unggahan di media sosial. Fenomena tentang bagaimana perempuan kemudian tertarik dengan berbagai produk make up dan jasa layanan kecantikan bahkan melakukan operasi plastik untuk mempercantik diri juga telah menjadikan dirinya sebagai obyek dari imajinasi atas kecantikan yang di reproduksi oleh dominant habitus

\footnotetext{
${ }^{9}$ Shoshana Zuboff, "Surveillance Capitalism and the Challenge of Collective Action", The Murphy Institute, City University of New York, (2019):3.

${ }^{10}$ Grenfell, M. "Pierre Bourdieu-Key Concepts", UK: Acumen Publishing, (2008), 14
} 
yang bergerak di dalam ruang digital. Here, habitus becomes the state of mind, the state of the body, and the state of being. ${ }^{11}$

Kekerasan simbolik yang masuk kedalam praksis sosial terepresentasi dalam aktifitas perempuan di sosial media. Dalam proses inilah tentu banyak kerentanan yang tidak diperhitungkan ketika data yang kita sajikan baik berupa identitas pribadi, foto, teks, maupun video bisa menjadi analisa pihak-pihak tertentu untuk melakukan pendekatan dengan tujuan melakukan kekerasan. Sebagai contoh ketika ide mengenai tubuh yang seksi dan langsing, wajah yang cantik serta kebebasan berekspresi menjadi dominant habitus yang dikembangkan, maka perempuan memiliki imajinasi untuk menjadi serupa agar bisa diterima dalam ruang digital tersebut. Penerimaan dalam arena ini bisa ditandai dengan jumlah orang yang menyukai foto, memberi komentar, dan bahkan memperoleh jumlah pengikut yang banyak dan mendapatkan dukungan/endorsement untuk menjadi influencer bagi produk-produk yang berkaitan. Hal yang ingin ditekankan disini bukan soal pembatasan ruang ekspresi seseorang atau khususnya perempuan dalam ruang digital melainkan bagaimana memberikan pemahaman dan kesadaran kritis atas potensi kekerasan yang muncul dengan terpampangnya "data diri" secara bebas di dunia maya.

Kembali pada pembahasan mengenai jenis-jenis KGBO yang bisa hadir dalam berbagai bentuk dan cara, secara praksis tubuh perempuan yang terekspos, identitas diri dan kehidupan privat seseorang yang termediasi dalam teks, gambar dan video menjadi hal yang mudah untuk diakses oleh banyak pihak dengan berbagai kepentingan. Berkembangnya dominant habitus tentang perempuanideal, kekerasan simbolik, dan terbukanya informasi terkait status individu menjadikan perempuan sebagai subyek sekaligus obyek yang rentan di dalam ruang digital.

\section{KESIMPULAN DAN REKOMENDASI KEBIJAKAN}

Surveilance capitalism dengan logika ekonomi yang digunakan telah menjadi basis bagi kemunculan berbagai bentuk kekerasan gender berbasis online dalam perkembangan dunia digital hari ini. Ruang digital yang kita manfaatkan hari ini bukanlah ruang yang bebas nilai tetapi justru sarat dengan berbagai kepentingan. Periode pandemic telah menyebabkan bergersernya aktifitas utama manusia menjadi aktifitas yang termediasi secara virtual. Kondisi tersebut menyebabkan tingginya ketergantungan kita pada penggunaan internet. Tingginya kasus kekerasan gender berbasis online bukan tidak mungkin akan terus meningkat apabila berbagai pihak masih belum menyiapkan tindakan edukatif, preventif dan regulatif.

Berangkat dari pembahasan yang telah dijabarkan ada dua rekomendasi yang diharapkan mampu menekan kekerasan gender berbasis online di Indonesia. Pertama, peningkatan literasi digital di kalangan masyarakat, 70\% masyarakat kita saat ini adalah masyarakat digital namun pemahaman terhadap cara kerja digital belum cukup digalakkan sampai ke level yang paling bawah yaitu individu. Pergerseran ke ruang digital hari ini merupakan perubahan habitus generasi hari ini dan generasi masa depan yang perlu dipahami sebagai urgensi bersama. Pengembangan literasi digital harus memiliki fokus pada pengetahuan kritis/ critical knowledge yang peka terhadap gender.

${ }^{11}$ Bourdieu, P, “Language and Symbolic Power”. Cambridge, Massachusetts: Harvard University . Press, (1983), 13 
Pengembangan literasi digital perlu dilihat sebagai sebuah program edukasi yang menyeluruh dan tidak hanya sektoral dan sementara. Literasi digital perlu menjadi agenda pendidikan yang digalakkan secara formal maupun informal. Sehingga diharapkan generasi hari ini dan kedepan lebih memiliki kepekaan dalam membaca posisi diri sebagai subyek politik yang berdaya dalam ruang digital. Individu diharapkan mampu memahami potensi terbentuknya kekerasan siber yang muncul dalam penggunaan internet beserta tindakan yang perlu dilakukan jika pengguna mengalami atau melihat adanya potensi kekerasan yang terbentuk.

Kedua, dari level makro Pemerintah melakukan percepatan terhadap pengesahan RUU PDP (Perlindungan Data Pribadi) di era digital. Hal ini akan memberikan dampak preventif sekaligus bersifat regulatif terhadap pengguna aktif internet di Indonesia. Ekosistem penggunaan internet harus dilihat lebih menyeluruh tidak hanya menyangkut penggunaan perorangan namun juga perusahaan yang mengelola data pribadi seperti platform sosial media, e-commerce, transportasi, bahkan peorangan yang mengelola UMKM melalui internet. Hal ini penting untuk diperhatikan agar tidak ada penyalahgunaan data pribadi yang berujung pada potensi terbentuknya berbagai kekerasan siber.

\section{DAFTAR PUSTAKA}

Buku

Bourdieu, P. 1983. Language and Symbolic Power. Cambridge, Massachusetts: Harvard University Press.

Grenfell, M. 2008. “Pierre Bourdieu-Key Concepts”, UK: Acumen Publishing, 4.

Jurnal

Angeliqa, Fitria dan Billy K. Sarwono. 2018. "Symbolic violence and the effort to silencing women in their positions as leaders (critics of the women leaders' habitus in advertising agencies)", 1-7 https://doi.org/10.1051/e3sconf/20187410015

Henry, Nicola, Asher Flynn \& Anastasia Powell. 2018. "Policing image-based sexual abuse: stakeholder perspectives, Police Practice and Research", 19:6, 565-581, https://doi.org/10.1080/15614263.2018.1507892

Maddocks, Sophie. 2018. "From Non-consensual Pornography to Image-based Sexual Abuse: Charting the Course of a Problem with Many Names", Australian Feminist Studies, 2-3, https://doi.org/10.1080/08164649.2018.1542592

Zuboff, Shoshana. 2019. "Surveillance Capitalism and the Challenge of Collective Action", The Murphy Institute, City University of New York, 1-20.

Zurmailis, Faruk, "Doksa, Kekerasan Simbolik dan Habitus yang Ditumpangi dalam Kontruksi Kebudayaan di Dewan Kesenian Jakarta”, Jurnal Bahasa dan Sastra, (2017): 1- 29 
Artikel Online

Dany, F. Wisnu Wardhana, 2021. "Pemerasan Seksual Manfaatkan Data Korban di Daring", https://www.kompas.id/baca/polhuk/2021/03/04/pemerasan-seksual-manfaatkan-datakorban-di-daring/

Riyanto, Galuh Putri.2021. "Jumlah Pengguna Internet Indonesia 2021 Tembus 202 Juta", Kompas.com, 23 Februari, https://tekno.kompas.com/read/2021/02/23/16100057/jumlahpengguna-internet- indonesia-2021-tembus-202-juta

Judith J, M Paschalia, 2021. "Pelaku Ekonomi Digital Butuh Otoritas Perlindungan Data”, 30 Maret. https://www.kompas.id/baca/ekonomi/2021/03/30/pelaku-ekonomi-digital-butuhotoritas-perlindungan-data/ 